\title{
Kinesiotaping w leczeniu obrzęku limfatycznego kończyny górnej u pacjentki po operacji raka piersi - studium przypadku
}

\section{Kinesiotaping - treatment of upper limb lymphoedema in patients after breast cancer surgery}

\author{
Agnieszka Lubińska, Hanna Mosiejczuk, Iwona Rotter \\ Samodzielna Pracownia Rehabilitacji Medycznej Pomorskiego Uniwersytetu Medycznego w Szczecinie \\ ul. Grudziądzka 31, 70-103 Szczecin \\ Kierownik: dr n. med. Iwona Rotter
}

\begin{abstract}
SUMMARY
Objective: The aim of this study was to examine the effectiveness of lymphatic kinesiotaping in patients after unilateral breast cancer surgery.

Material and methods: Complex decongestive therapy in patients after right-side breast-conserving surgery was done once a week for 2 months (from November to December 2014). It involved manual lymph drainage and lymphatic application of kinesiotaping. An original kinesiology tape (Nitto Denko, Japan) was used for the treatment. Lymphoedema was measured at the
\end{abstract}

\section{STRESZCZENIE}

Wstęp: Celem pracy było zbadanie skuteczności działania aplikacji limfatycznej kinesiotapingu u pacjentki po jednostronnej operacji raka piersi.

Materiał i metody: Przeprowadzono kompleksową terapię przeciwobrzękową u pacjentki po prawostronnym zabiegu oszczędzającym, stosując raz w tygodniu przez 2 miesiące (od listopada do grudnia 2014 r.) manualny drenaż limfatyczny i aplikację limfatyczną plastra kinesiotaping. Do terapii uży to plastry Nitto Denko pochodzące z Japonii. Obrzęk zmierzono na początku i końcu terapii miarką centymetrową w pozycji siedzącej beginning and at the end of treatment in centimetres in specific places: metatarsal, wrist, at the mid-length of the forearm, in the elbow and at the mid-length of the upper arm. The volume of oedema was assessed at the beginning and at the end of the treatment.

Results: The reduction of lymphoedema in different places. Conclusions: Kinesiotaping may be an alternative method in relation to the use of materials in complex decongestive therapy. However, this technique requires further research.

Key words: kinesiotaping, lymphoedema, breast cancer.

w określonych miejscach: śródręcze, nadgarstek, połowa przedramienia, łokieć i połowa ramienia. Oceniano wielkość obrzęku na początku i pod koniec trwania terapii.

Wyniki: Uzyskano zmniejszenie obrzęku limfatycznego w poszczególnych miejscach.

Wnioski: Kinesiotaping może być alternatywną metodą w stosunku do używania materiałów uciskowych w kompleksowej terapii przeciwobrzękowej, jednak technika ta wymaga większej ilości badań.

Słowa kluczowe: kinesiotaping, obrzęk limfatyczny, nowotwór piersi.
Rak piersi jest najczęściej występującym nowotworem u kobiet. Szacuje się, że stanowi on ok. 20\% wszystkich nowotworów i jest główną przyczyną umieralności spowodowanych nowotworami wśród kobiet w Polsce [1]. Jednym z najważniejszych powikłań pooperacyjnych leczenia raka piersi jest wtórny obrzęk limfatyczny dołu pachowego oraz kończyny górnej po stronie operowanej. Wiele wyników badań wskazuje na to, że obrzęk po operacjach raka piersi pojawia się u 22-43\% kobiet [2]. Na wielkość obrzęku mają wpływ: rodzaj operacji (zabieg oszczędzający czy całkowita mastektomia), radioterapia i wyjściowy wskaźnik masy ciała pacjenta [3]. Wyróżnia się 4 stadia obrzęku:

Stadium o (ukryte) - ogniskowe fibrosklerotyczne przemiany tkanki; diagnostyka: limfografia izotopowa.

Stadium 1 (odwracalne) - obrzęk z dużą zawartością białka, test odcisku palca pozytywny, wysokie ułożenie kończyny redukuje obrzęk.
Stadium 2 (nieodwracalne) - zwiększona fibroskleroza, twardy obrzęk niereagujący na wysokie ułożenie kończyny.

Stadium 3 (elephantiasis) - obszerna fibroskleroza i symptomy, takie jak w stadium 1; prowadzi do inwalidztwa.

Powszechnie wiadomo, że najlepszą formą redukcji obrzęku limfatycznego jest kompleksowa terapia przeciwobrzękowa, która obejmuje: manualny drenaż limfatyczny, terapię uciskowa za pomocą bandaży lub pończoch, gimnastykę (ćwiczenia udrażniające wraz z terapią oddechową), właściwą pielęgnację skóry oraz edukację pacjenta [4, 5, 6]. Drenaż limfatyczny zapoczątkował Emil Vodder, a rozwinęli go Asdonk i Foldi [7]. Jest to metoda mechaniczna wykonywana manualnie, służąca polepszeniu i wspomaganiu naturalnego mechanizmu fizjologicznego drenażu, przesuwaniu cieczy obrzękowej i mobilizacji fibronów. Manualny drenaż limfatyczny bazuje na czterech chwytach Voddera: stałych ruchach okrężnych, chwycie obrotowym, pompującym i czerpiącym. Dany chwyt stosuje się ok. 5-7 razy, następnie przesuwa się powoli w kierunku 
dystalnym. Inną metodą opracowaną przez Kenzo Kase, stosowaną w redukcji obrzęku limfatycznego, jest kinesiotaping [8], który służy pobudzeniu motoryki naczyń limfatycznych, poprawia procesy limfotwórcze i utrzymuje je w maksymalnej intensywności pracy. Można go stosować zamiast kompresjoterapii, po skończonym ręcznym drenażu limfatycznym. Wśród zalet kinesiotapingu należy wymienić możliwość dłuższego noszenia, poczucie większego komfortu, nieograniczenie ruchomości w czynnościach codziennych oraz możliwość kąpieli. Tradycyjne bandażowanie za pomocą różnych materiałów uciskowych okazuje się być drogim i nie do końca wygodnym dla pacjenta sposobem kompresji ze względu na brak możliwości umycia się oraz uczucie wzmożonej potliwości, zwłaszcza w okresach letnich.

Pomimo coraz częstszego stosowania kinesiotapingu u kobiet po operacjach raka piersi, ukazały się jedynie pojedyncze prace opisujące skuteczność działania tych taśm w redukcji obrzęku limfatycznego [9, 10]. Plastry kinesiotaping aplikuje się bezpośrednio na skórę, są hipoalergiczne, działają 24 godz. na dobę przez 3-5 dni, a zwykłe bandażowanie czy kompresja działa tylko przez 24 godz., potem wymaga ponownego nałożenia. Kinesiotaping może być stosowany jako oddzielna metoda terapeutyczna lub jako uzupełnienie innych metod. Wyróżnia się aplikacje mechaniczną, powięziową, przestrzenną, więzadłową, funkcjonalną i limfatyczną. Każda technika wymaga właściwego naklejenia zgodnie z ogólnie przyjętymi zasadami przez wykwalifikowanego fizjoterapeutę.

\section{OPIS PACJENTA}

Pacjentem była kobieta w wieku 67 lat z rozpoznanym rakiem sutka prawego, po leczeniu chirurgicznym (zabieg oszczędzający w 2007 r.), z następową radioterapią. Po 12 miesiącach od zabiegu operacyjnego wystąpił obrzęk kończyny górnej prawej mimo stosowania przez pacjentkę standardów postępowania, takich jak: ćwiczenia ręki, automasaż i pozycje ułożeniowe. Kobieta zgłosiła się do fizjoterapeuty. Na podstawie aktualnego stanu wiedzy zaproponowano jej różne formy kompleksowej terapii przeciwobrzękowej, takie jak:

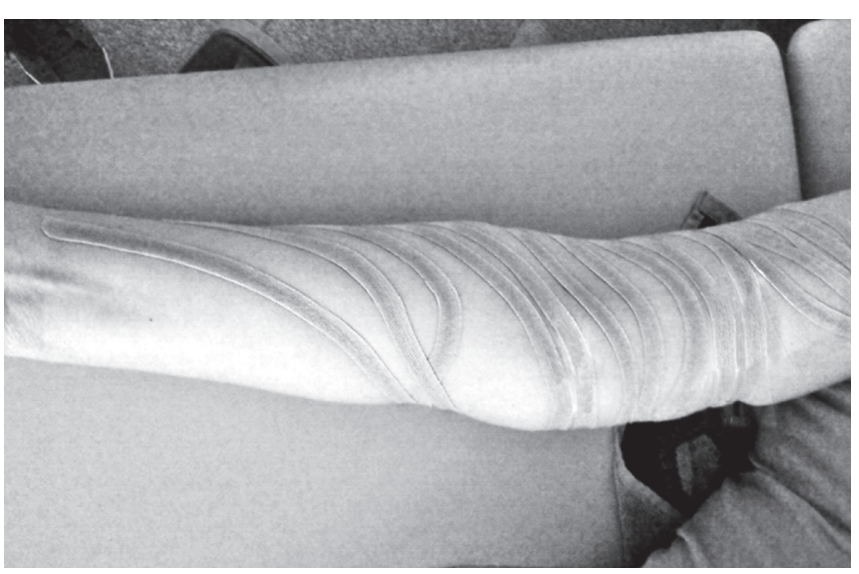

RYCINA 1. Kinesiotaping manualny drenaż limfatyczny z kompresjoterapią za pomocą rękawa uciskowego lub drenaż w połączeniu z aplikacją limfatyczną kinesiotapingu. Pacjentka zgodziła się na zastosowanie tapingu. Zastosowano terapię przeciwobrzękową przez 2 miesiące raz w tygodniu, od listopada do grudnia $2014 \mathrm{r}$. (w sumie 8 razy) za pomocą manualnego drenażu limfatycznego trwającego 1 godz. wraz z aplikacją limfatyczną kinesiotapingu. Aplikacja kinesiotapingu została przeprowadzona w następujący sposób:

1. Wycięcie kinesiotapingu na długość kończyny górnej.

2. Pozostawienie ok. $4 \mathrm{~cm}$ bazy, resztę tapingu pocięto na 4-5 podłużnych kawałków.

3. Naklejenie kinesiotapingu bez naprężenia, spiralnie, przez całą kończynę górną (ryc. 1).

Pacjentka nosiła aplikację ok. 4-5 dni i po tym okresie przychodziła ponownie na terapię.

\section{WYNIKI}

Na początku i na końcu terapii dokonano pomiaru obrzęku miarką centymetrową w pozycji siedzącej. Wyniki pomiarów przedstawiono w tabeli 1 .

TABELA 1. Pomiary obrzęku w pozycji siedzącej przed terapią i po terapii

\begin{tabular}{lcc}
\multicolumn{1}{c}{ Parametry } & Przed terapią (cm) & Po terapii (cm) \\
\hline Śródręcze & 20 & 20 \\
\hline Nadgarstek & 16 & 15 \\
\hline Połowa przedramienia & 23 & 21 \\
\hline Łokieć & 25 & 24 \\
\hline Połowa ramienia & 27 & 26
\end{tabular}

\section{OMÓWIENIE}

Z powyższych danych wynika, że w poszczególnych miejscach pomiarowych uzyskano niewielkie zmniejszenie obrzęku limfatycznego. Wiele wyników badań wskazuje jednak na dobre rezultaty leczenia obrzęku limfatycznego za pomocą plastrów kinesiotaping. Jeziorski, Andersen i wsp. oraz Johansson uważają, iż aplikacje limfatyczne są kluczowym elementem kompleksowej terapii przeciwobrzękowej [11, 12,13].

Według Pyszory [14] kinesiotaping może stanowić cenne uzupełnienie terapii pacjentek z obrzękiem chłonnym, jednak metoda ta wymaga jeszcze przeprowadzenia wielu badań. Pop i wsp. wskazują na pozytywny efekt działania aplikacji limfatycznej kiensiotapingu w odniesieniu do zwiększenia ruchomości stawów kończyny obrzękniętej, jak również poprawy siły uścisku dłoni [15].

\section{WNIOSKI}

Aplikacja limfatyczna kinesiotapingu wraz z manualnym drenażem limfatycznym może dać pozytywne rezultaty w postaci 
zmniejszenia obrzęku limfatycznego w poszczególnych miejscach. Ze względu na wygodę noszenia, długość działania, możliwości mycia się, metoda kinesiotapingu może zastąpić tradycyjną metodę redukcji obrzęku limfatycznego z użyciem materiałów kompresyjnych i tym samym polepszyć jakość życia pacjentek, ale terapie takie wciąż wymagają przeprowadzenia większej liczby badań.

\section{PIŚMIENNICTWO}

1. Woźniewski M., Kornafel J.: Rehabilitacja w onkologii. Elsevier Urban \& Partner, Wrocław 2010, 181-197.

2. Kużdżał A.: Atlas rehabilitacji ruchowej. Forum, Poznań 2009, 1-20.

3. Devoogdt N., Christiaens M., Geraerts I., Truijen S.: Effect of manual lymph drainage in addition to guidelines and exercise therapy on arm lymphedema related to breast cancer: randomised controlled trial. BMJ. 2011, 326-343.

4. Randheer S., Kadambari D., Srinivasan K., Bhuvaneswari V., Bhanumathy M., Salaja R.: Comprehensive decongestive therapy in postmastectomy lymphedema: an Indian perspective. Indian J Cancer. 2011, 48 (4), 397-402.

5. Woods M.: Patient's perceptions of breast-cancer-related ly mphoedema. Eur J Cancer Care. 1993, 2, 125-128.
6. Box R.C., Reul-Hircke H.M., Bulloch-Saxton J.E., Furnival C.M.: Physiotherapy after breast cancer surgery: results of a randomised controlled study to minimise lymphoedema. Breast Cancer Res Treat. 2002, 75, 51-64.

7. Foldi M., Strossenreuther R.: Podstawy manualnego drenażu limfatycznego. Urban \& Partner, Wrocław 2010, 60-72.

8. Mikołajewska E.: Kinesiotaping - rozwiązania wybranych problemów funkcjonalnych. PZWL, Warszawa 2011, 15-142.

9. Lipińska A., Śliwiński Z., Kiebzak W., Senderek T., Kirenko T.: Wpływ aplikacji kinesiotapingu na obrzęk limfatyczny kończyny górnej u kobiet po mastektomii. Fizjoter Pol. 2007, 7, 258-269.

10. Tsai H.J., Hung H.C., Jang J.L., Huang C.S., Tsauo J.Y.: Could kinesiotape replace the bandage in decongestive lymphatic therapy for breast-cancer-related lymphedema? A pilot study. Support Care Cancer. 2009, 17 (11), 1353-1360.

11. Jeziorski A.: Obrzęk limfatyczny jako powikłanie leczenia chorych na raka piersi - przegląd piśmiennictwa. Onkol Pol. 1999, 2, 121-125.

12. Andersen L., Højris I., Erlandsen M., Andersen J.: Treatment of breast-cancer-related lymphedema with or without manual lymphatic drenaige. Acta Oncol. 2000, 39, 399-405.

13. Johansson K.: Is physiotherapy useful to the breast cancer patient? Acta Oncol. 2005, 44, 423-424.

14. Pyszora A.: Kompleksowa fizjoterapia pacjentów z obrzękiem limfatycznym. Med Paliat Prakt. 2010, 4, 23-29.

15. Pop B., Borowska B., Tymczak M., Hałas I., Banaś J.: The influence of kinesiology taping on the reduction of lymphedema among woman after mastectomy-preliminary study. Contemp Oncol. 2014, 18 (2), 124-129. 